\title{
PENERAPAN PENGGUNAAN SERBUK BIJI KELOR SEBAGAI KOAGULAN PADA PROSES KOAGULASI FLOKULASI LIMBAH CAIR PABRIK TAHU DI SENTRA INDUSTRI TAHU KOTA MALANG
}

\author{
Harimbi Setyawati ${ }^{1)}$, ST. Salamia, LA ${ }^{2)}$, Sanny Andjar Sari ${ }^{3)}$ \\ ${ }^{1)}$ Program Studi Teknik Kimia, Fakultas Teknologi Industri, \\ Institut Teknologi Nsional Malang \\ ${ }^{2), 3)}$ Program Studi Teknik Industri Fakultas Teknologi Industri, \\ Institut Teknologi Nsional Malang
}

\begin{abstract}
Abstrak, Limbah cair industri tahu mengandung bahan-bahan organik yang sangat tinggi. Senyawa-senyawa organik di dalam limbah cair tersebut berupa protein, karbohidrat, lemak dan minyak. Berdasarkan analisa limbah cair industri kecil tahu di karangploso diketahui bahwa limbah cair industri tahu mengandung COD (1247 mg/l), BOD (997 mg/l), TSS $(587,5 \mathrm{mg} / \mathrm{l})$ dan $\mathrm{pH} 3,7$. Oleh sebab itu, limbah cair tersebut harus diolah terlebih dahulu sebelum dibuang ke lingkungan untuk mengurangi kandungan pencemar yang menyertai limbah tersebut. Salah satu koagulan alternatif yang dapat digunakan adalah serbuk biji kelor. Kegiatan pengabdian ini menggunakan serbuk biji kelor dengan kadar air $10 \%$. Variasi dosis koagulan yang digunakan 2000, 3000, 4000, $5000 \mathrm{mg} / 500 \mathrm{ml} \mathrm{limbah} \mathrm{cair} \mathrm{tahu,}$ ukuran koagulan 70 mesh dengan $\mathrm{pH}$ awal adalah 3,7 . Waktu pengandukan optimum yang diperoleh adalah 2-3 menit dengan penurunan COD $280 \mathrm{mg} / \mathrm{L}$, BOD $112 \mathrm{mg} / \mathrm{L}$, TSS 100,4 pada dosis koagulan $2000 \mathrm{mg} / 500 \mathrm{ml}$, dan ukuran partikel koagulan 70 mesh dengan $\mathrm{pH}$ akhir adalah 3,9 , sehingga dapat disimpulkan bahwa biji kelor dapat digunakan sebagai koagulan yang efektif karena persentase penurunan yang diperoleh di atas $50 \%$.
\end{abstract}

Kata Kunci: Limbah Cair Industri Tahu, Biji Kelor, COD, BOD dan TSS

Industri tahu pada umumnya menghasilkan air limbah yang polutif, dengan kadar BOD 900-3500 mg/l dan COD 1700-7300 mg/l. Limbah cair tahu ini pada umumnya langsung dibuang ke sungai yang menyebabkan kematian organisme perairan karena kekurangan oksigen. Jika dibuang ke sawah akan menghasilkan gas metan yang menyebabkan unsur hara didalam tanah menjadi tidak seimbang yang akan berdampak pada bulir padi menjadi puso atau kosong (Novarina, 2015). Untuk menurunkan nilai BOD dan COD limbah, perlu dilakukan pengurangan zat-zat organik yang terkandung di dalam limbah sebelum dibuang ke perairan (Jatu, 2010). 
Tahu merupakan salah satu makanan tradisional yang digemari oleh seluruh lapisan masyarakat Indonesia. Tahu mengandung gizi yang baik diantaranya mengandung protein, karbohidrat, dan lemak. Industri tahu di Indonesia rata-rata masih dilakukan dengan teknologi yang sangat sederhana sehingga tingkat efisiensi penggunaan sumber daya (air dan bahan baku) dirasakan masih rendah dan tingkat produksi limbahnya juga relatif tinggi.

Limbah cair yang dihasilkan dari industri tahu mengandung bahan organik tinggi dan kadar BOD sebesar $997 \mathrm{mg} / \mathrm{L}$, COD sebesar $1247 \mathrm{mg} / \mathrm{L}$, dan TSS yang cukup tinggi sebesar $587,5 \mathrm{mg} / \mathrm{L}$, sedangkan menurut Pergub Jatim tahun 2013 kadar buang air limbah yaitu BOD sebesar 150 $\mathrm{mg} / \mathrm{L}$, COD sebesar $300 \mathrm{mg} / \mathrm{L}$, dan TSS sebesar $200 \mathrm{mg} / \mathrm{L}$. Jika limbah langsung dibuang ke badan air, jelas sekali akan menurunkan daya dukung lingkungan. Sehingga industri tahu memerlukan suatu pengolahan limbah untuk mengurangi resiko beban pencemaran yang ada.[subekti sri, 2011].

Biji kelor dapat dipergunakan sebagai salah satu koagulan alami alternatif yang tersedia secara lokal. Efektivitas koagulasi biji kelor ditentukan oleh kandungan protein kationik. Keuntungan penggunaan koagulan alami seperti serbuk biji kelor adalah tanaman tersebut mudah ditemukan didaerah iklim tropis. Selain itu, koagulan alami dapat membentuk flok yang lebih kuat terhadap gesekan pada saat aliran turbulen dibandingkan dengan koagulan kimia.[S.D.R utami,2012].
Dalam kegiatan pengabdian masyarakat ini akan dilaksanakan penyuluhan kepada pemilik maupun karyawan di industri tahu tentang mengoptimalkan kinerja serbuk biji kelor sebagai koagulan organik dalam menurunkan COD, BOD, TSS (Total Suspended Solid), dan juga turbiditas pada limbah cair industri tahu.

Pengabdian masyarakat ini mempunyai kegunaan sebagai berikut:

1. Memberikan informasi tentang kemampuan optimum serbuk biji kelor sebagai koagulan organik dalam menurunkan COD, BOD, TSS (Total Suspended Solid), dalam limbah industri tahu.

2. Menambah pengetahuan mengenai pengolahan limbah cair industri tahu di Indonesia.

3. Mengoptimalkan pengolahan limbah cair industri tahu dengan menggunakan serbuk biji kelor.

\section{Limbah Cair industri Tahu}

Limbah padat industri tahu belum dirasakan dampaknya karena limbah padat industri tahu bisa dimanfaatkan sebagai pakan ternak.. [hanry,] Sedangkan limbah cair merupakan bagian terbesar dan berpotensi mencemari lingkungan.

Limbah cair industri tahu mengandung bahan-bahan organik yang pada umumnya sangat tinggi. Senyawa-senyawa organik di dalam air limbah buangan tersebut dapat berupa:

- Protein

- Karbohidrat

- Lemak

- Dan minyak

Di antara senyawa-senyawa tersebut, protein dan lemaklah yang jumlahnya paling besar di dalam limbah cair tahu. 
Semakin lama, jumlah dan jenis bahan organik yang terkandung ini akan semakin banyak, dalam hal ini akan menyulitkan pengelolaan limbah, karena beberapa zat sulit diuraikan oleh mikroorganisme di dalam air limbah tahu tersebut.[ayu,2013]

A. Karakteristik Limbah Cair Industri Tahu

Karakteristik buangan industri tahu meliputi dua hal, yaitu

- Karakteristik Fisika

Meliputi padatan total, padatan tersuspensi, suhu, warna, dan bau.

- Karakteristik kimia

Meliputi bahan organik, bahan anorganik dan gas.

Suhu buangan industri tahu berasal dari proses pemasakan kedelai. [coniwanti, 2013] Suhu air limbah tahu berkisar $37-45^{\circ} \mathrm{C}$, kekeruhan 535585 FTU, warna 2.225-2.250 Pt.Co,amonia 23,3-23,5 mg/1, BOD5 6.000-8.000 mg/1 dan COD 7.500$14.000 \mathrm{mg} / 1$. [fibria,2007] Senyawasenyawa tersebut mencapai $40 \%-60 \%$ protein, $25 \%-50 \%$ karbohidrat, dan $10 \%$ lemak. Air buangan industri tahu kualitasnya bergantung dari proses yang digunakan. Apabila air prosesnya baik, maka kandungan bahan organik pada air buangannya biasanya rendah. Komponen terbesar dari limbah cair tahu yaitu protein (Ntotal) sebesar 226,06 434,78 mg/l. [coniwanti, 2013]

B. Dampak Limbah Industri Tahu

Limbah cair yang dihasilkan pada proses pembuatan tahu mengandung padatan tersuspensi maupun terlarut, akan mengalami perubahan fisika, kimia dan akan menimbulkan gangguan terhadap kesehatan karena menghasilkan zat beracun. Bila dibiarkan begitu saja, air limbah akan berubah warnanya menjadi cokelat kehitaman dan berbau busuk. Apabila air limbah ini merembes ke dalam tanah yang dekat dengan sumur maka air sumur itu tidak dapat dimanfaatkan lagi. Apabila limbah ini dialirkan ke sungai maka akan mencemari sungai dan bila masih digunakan akan menimbulkan gangguan kesehatan.[coniwanti,2013].

Selain itu, pencemaran bahan organik limbah industri tahu adalah gangguan terhadap kehidupan biotik. Turunnya kualitas air perairan akibat meningkatnya kandungan bahan organik. [fibria,2007]

\section{Koagulasi-Flokulasi}

Koagulasi-flokulasi merupakan suatu proses yang diperlukan untuk menghilangkan material limbah berbentuk suspense atau koloid. Koloid merupakan suatu partikelpartikel yang tidak dapat mengendap dalam waktu tertentu dan tidak dapat dihilangkan dengan proses perlakuan fisika biasa.[coniwanti,2013]

Koagulasi itu sendiri adalah proses destabilisasi partikel senyawa koloid dalam limbah cair. Dapat dikatakan pula suatu proses pengendapan dengan menambahkan bahan koagulan ke dalam limbah cair sehingga terjadi endapan pada dasar tangki pengendapan.[suharto,2011]

Prinsip dasar proses koagulasi adalah terjadinya gaya tarik menarik antara ion-ion negatif disuatu pihak dengan ion-ion positif di pihak lain. Yang bertindak sebagai ion negatif adalah partikel-partikel yang terdiri 
dari zat-zat organik (partikel koloid), mikoorganisme dan bakteri. [bangun,2013]

Sedangkan flokulasi merupakan proses kelanjutan dari proses koagulasi, dimana mikroflok hasil koagulasi mulai menggumpalkan partikel-partikel koloid menjadi flokflok yang lebih besar yang dapat diendapkan dan proses ini dibantu dengan pengadukan lambat.

Proses koagulasi-flokulasi tidak dapat dipisahkan dalam pengolahan limbah cair industri karena kedua proses ini selalu dilakukan bersama. Pembentukan makroflok dalam proses flokulasi terjadi karena tumbukantumbukan antara partikel koloid.[bangun,2013]

\section{Koagulan}

Koagulan adalah bahan kimia yang dibutuhkan air untuk membantu proses pengendapan partikel-partikel kecil yang tak dapat mengendap dengan sendirinya. Koagulan yang biasa digunakan dalam industri pengolahan air adalah koagulan kimia seperti tawas, PAC, ferri klorida, ferri sulfat, dan polymer kation. Meskipun koagulan kimia lebih efektif dari koagulan alami akan tetapi koagulan kimia dalam dosis yang tinggi dapat menyebabkan endapan yang sulit untuk ditangani. Sehingga koagulan alami adalah salah satu alternatif yang dapat digunakan sebagai pengganti koagulan kimia. Koagulan alami yang biasa digunakan pada umumnya berasal dari biji tanaman.[coniwati,2013]. Syarat koagulan, yaitu:

1. Kation trivalen

2. Non toksik

3. Tidak terlarut pada batasan $\mathrm{pH}$ netral

Pada proses koagulasi, partikelpartikel koloid menarik ion-ion positif dari zat kimia yang ditambahkan sebagai koagulan. Koagulan dengan konsentrasi yang pekat membentuk lapisan pada permukaan partikel koloid. Lapisan tersebut dikelilingi oleh ion-ion negatif dan secara perlahan-lahan bercampur dengan ionion positif. Lapisan ion positif dikenal dengan istilah lapisan kokoh, sedangkan lapisan yang mengelilingi ion positif dikenal dengan lapisan difus. Lapisan difus ini kemudian terkontraksi dan menghilangkan lapisan kokoh, sehingga menyebabkan terjadinya gaya tarik-menarik antar partikel-partikel koloid.

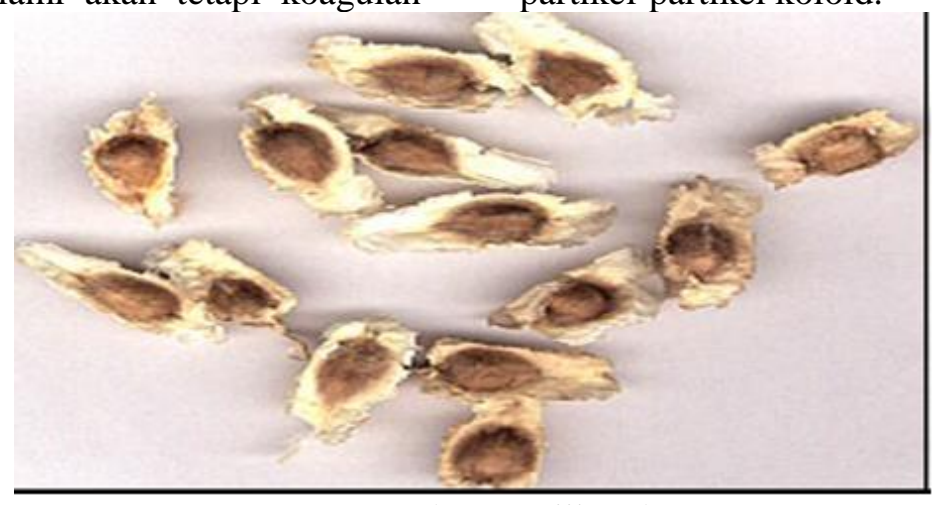

Gambar 1. Biji Kelor 
Moringa oliefera di Indonesia dikenal seabagi kelor. Tumbuhan ini termasuk jenis tumbuhan perdu yang dapat memiliki batang 7-11 meter. Kelor dapat berkembang biak dengan baik pada daerah yang mempunyai ketinggian tanah 300-500 meter. [indra,2010] Buah kelor berbentuk polong segitiga memanjang sekitar 30 $50 \mathrm{~cm}$, yang biasa disebut klentang. buah kelor berisi $15-25$ biji berwarna coklat kehitaman. [nila,2013]

Biji kelor dapat dipergunakan sebagai salah satu koagulan alami

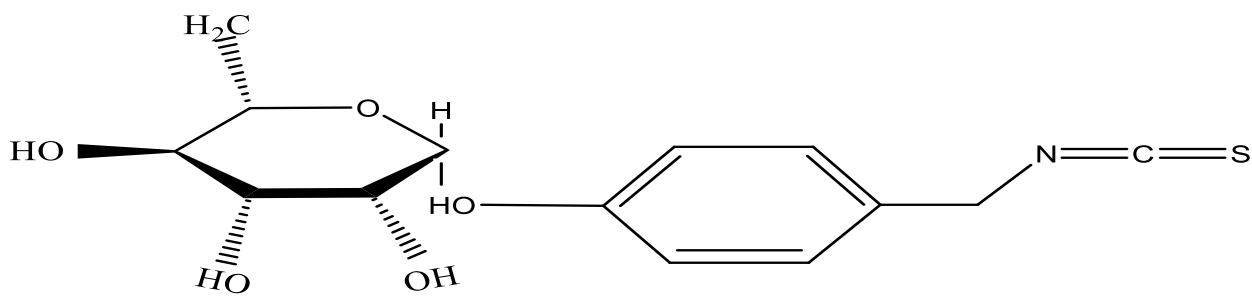

Gambar 2. Struktur Kimia 4 $\alpha$ L-Rhamnosyloxy-Benzyl-Isothiocyanate [wahyudi,2012]

Zat aktif itu mampu mengadsorbsi partikel-partikel air limbah. Dengan pengubahan bentuk menjadi bentuk yang lebih kecil, maka zat aktif dari biji kelor tersebut akan semakin banyak karena luas permukaan biji kelor semakin besar. Apabila kandungan air di dalam biji kelor besar, maka kemampuannya dalam menyerap limbah cair semakin kecil karena zat aktif tersebut tidak berada di permukaan biji kelor tetapi tertutupi oleh air sehingga kelembaban biji kelor harus kecil .[ayu,2013]

Serbuk biji kelor ketika diaduk dengan air, protein terlarutnya memiliki muatan positif. Fakta ini sangat menguntungkan karena alternatif yang tersedia secara lokal. Biji kelor yang dipergunakan adalah yang matang atau tua yang memiliki kadar air kurang dari 10\%.[riko,2013] Efektivitas koagulasi biji kelor ditentukan oleh kandungan protein kationik. Zat aktif yang terkandung dalam biji kelor yaitu $4 \alpha \mathrm{L}-$ rhamnosyloxy-benzyl-

isothiocyanate.[coniwanti, 2013] berikut adalah struktur kimia $4 \alpha \mathrm{L}$ rhamnosyloxy-benzyl-isothiocyanate: 
terhadap gesekan pada saat aliran turbulen dibandingkan dengan koagulan kimia.[S.D.R utami,2012]

Koagulan serbuk biji kelor memiliki keuntungan tambahan yaitu bersifat antimikroba. [syahru rahmadani,2013] Mekanisme yang paling mungkin terjadi dalam proses koagulasi dengan serbuk biji kelor [Moringa oleifera] adalah adsorpsi dan netralisasi tegangan koloid.[hadi purnomo,2012].
Dalam proses koagulasinya, serbuk biji kelor memberikan pengaruh yang kecil terhadap derajat keasaman dan konduktifitas. Bahan koagulan dalam serbuk biji kelor adalah protein kationik yang larut dalam air. Hal ini menunjukkan bahwa larutan ini didominasi oleh tegangan positif meskipun merupakan campuran heterogen yang kompleks. [coniwanti,2013].

Tabel 1. Unsur-Unsur Alami Yang Terkandung Per 100 Gram Biji Kelor Kering

\begin{tabular}{llll}
\hline No & \multicolumn{1}{c}{ Komposisi } & Berat & Satuan \\
\hline 1 & Air & $4.08 \mathrm{gr}$ & gram \\
\hline 2 & Protein & $38.4 \mathrm{gr}$ & gram \\
\hline 3 & Minyak dan Lemak & $34.7 \%$ & $\%$ \\
\hline 4 & Ekstrak & $16.4 \mathrm{gr}$ & gram \\
\hline 5 & Serat & $3.5 \mathrm{gr}$ & gram \\
\hline 6 & Abu & $3.2 \mathrm{gr}$ & gram \\
\hline
\end{tabular}

Tabel 2. Unsur-Unsur Kimia Yang Terkandung Biji Kelor

\begin{tabular}{ll}
\hline Komposisi & Jumlah $(\%)$ \\
\hline Kalsium & 3,76 \\
\hline Sukrosa & 5,5 \\
\hline Kalium & 1,43 \\
\hline Magnesium & 0,96 \\
\hline $\mathrm{CaO}$ & 0,4 \\
\hline $\mathrm{P} 2 \mathrm{O} 5$ & 1,1 \\
\hline $\mathrm{K} 2 \mathrm{O}$ & 0,8 \\
\hline
\end{tabular}

\section{METODE}

Bahan baku dalam percobaan ini adalah limbah cair industri tahu yang dihasilkan dari proses penggumpalan pada proses pembuatan tahu. Limbah cair yang diambil adalah limbah cair tahu berat dari

Prosedur Penelitian
1. Pembuatan koagulan serbuk biji kelor kadar air $10 \%$

Serbuk biji kelor yang akan digunakan sebagai koagulan sebelumnya diturunkan kadar airnya hingga menjadi 10\%. Serbuk biji kelor terlebih dahulu diayak menggunakan ayakan mesh ukuran 70 mesh. Setelah itu serbuk biji 
kelor yang sudah diayak ukuran 70 mesh dioven \pm 2 jam dengan suhu 105 oC, setelah itu dilakukan penimbangan hingga mencapai kadar $10 \%$.

2. Proses penurunan BOD, COD, dan TSS pada air limbah industri tahu. Prosedur penelitian terhadap berbagai variasi dosis koagulan terhadap nilai turbidity, TSS, BOD dan COD limbah cair industeri tahu

- Sampel limbah cair industri tahu

- Analisa COD, BOD, TSS dan pH untuk sampel awal limbah.

- Limbah dimasukkan ke dalam 4 buah beaker glass dengan volume masing-masing $500 \mathrm{ml}$

- Penambahan koagulan biji kelor dalam sampel dengan dosis tertentu $(2000,3000$, 4000, dan $5000 \mathrm{mg} / \mathrm{L}$ ), dilanjutkan dengan proses koagulasi-flokulasi dengan alat flokulator.
- Sampel kemudian diaduk cepat dengan waktu tertentu (2,3,4 dan 5 menit) dengan kecepatan pengadukan 100 rpm, diikut dengan pengadukan lambat $40 \mathrm{rpm}$ selama 15 menit. Setelah pengadukan, diendapkan selama 25 menit setelah itu, penyaringan denga kertas saring.

- Setelah sedimentasi dan penyaringan hasil diambil dan dilakukan analisa kembali. Dan diambil kesimpulan

\section{HASIL DAN PEMBAHASAN}

1. COD

Dari uji analisa sampel ada beberapa sample yang sesuai dengan standard kelayakan limbah industri tahu di Jawa Timur, berdasar pada PERGUBJATIM-722013, didapatkan hasil sebagai berikut:

Tabel 1. Hasil Uji Analisa Sampel Tentang COD

\begin{tabular}{|c|c|c|c|c|}
\hline \multirow{2}{*}{ Massa } & \multicolumn{4}{|c|}{ Nilai COD (mg/L) } \\
\cline { 2 - 5 } & 20 menit & 40 menit & 60 menit & 80 menit \\
\hline 100 gramm & 32 & 288 & 416 & 512 \\
\hline 200 gram & 160 & 290 & 736 & 832 \\
\hline 300 gram & 192 & 305 & 800 & 864 \\
\hline 400 gram & 256 & 320 & 832 & 896 \\
\hline
\end{tabular}




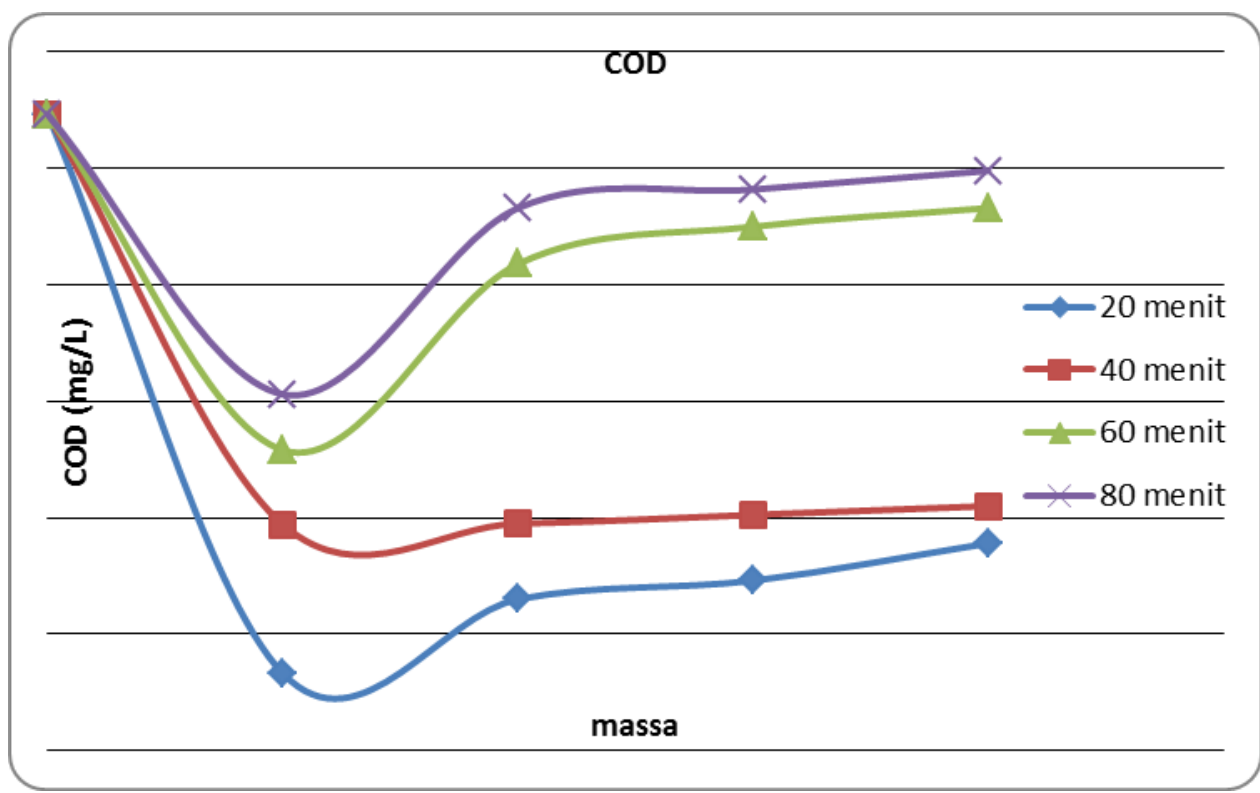

Gambar 4. Hasil Uji Analisa Tentang COD

Chemical Oxygen Demand atau kebutuhan oksigen kimia (KOK) adalah jumlah oksigen $(\mathrm{mgO} 2)$ yang dibutuhkan untuk mengoksidasi zat-zat organik yang ada dalam satu liter sampel air. Nilai COD yang diperbolehkan untuk industri tahu berdasarkan PERGUBJATIM-72-2013 adalah $300 \mathrm{mg} / \mathrm{L}$. Dari hasil analisa sample ada beberapa sample yang tidak memenuhi ambang batas nilai COD berdasarkan PERGUBJATIM72-2013. Waktu kontak optimum pada penelitian ini adalah 20 menit, pada waktu kontak 0-20 menit terjadi penurunan kadar COD yang signifikan. Penurunan nilai adsorbsi terjadi secara terus menerus pada waktu kontak 40-80 menit. Hal ini sesuai dengan teori yang telah diuraikan diatas bahwa semakin lama waktu kontak akan semakin baik dalam proses adsorbsi hingga didapatkan waktu optimum dalam proses penyerapan, setelah waktu optimum didapatkan maka proses penyerapan cenderung berkurang, hal dikarenakan adanya kemungkinan sebagian kecil dari adsorben ikut terbawa oleh larutan sehingga kemampuan penyerapan berkurang. Selain itu juga disebabkan adsorben telah mencapai titik jenuh dalam proses adsorpsi, sehingga proses penyerapan menurun setelah tercapai waktu optimum.

Waktu kontak berbanding lurus dengan bertambahnya massa dimana semakin banyak semakin banyak massa adsorben semakin tinggi pula kadar COD, hal ini disebabkan karena massa arang aktif sekam padi yang diberikan terlalu banyak sehingga antar arang aktif sendiri saling berdesakan dan menyebabkan interaksi arang aktif sekam padi dengan limbah cair tahu kurang efektif. 
Pada penelitian ini didapatkan waktu kontak optimum adalah 20 menit dengan massa adsorben optimum 100 gram. Dimana terjadi penurunan yang signifikan dari nilai COD limbah awal adalah $992 \mathrm{mg} / \mathrm{L}$ menjadi $32 \mathrm{mg} / \mathrm{L}$.

\section{BOD}

Dari uji analisa sampel sesuai dengan standard kelayakan limbah industri tahu di Jawa Timur, berdasar pada PERGUBJATIM-72-2013, didapatkan hasil sebagai berikut:

Tabel 2. Hasil Uji Analisa Sampel Tentang BOD

\begin{tabular}{|c|c|c|c|c|}
\hline \multicolumn{4}{|c|}{ Massa Waktu } & \multicolumn{4}{|c|}{ Nilai BOD (mg/L) } \\
\cline { 2 - 5 } & 20 menit & 40 menit & 60 menit & 80 menit \\
\hline \hline 100 gram & 16,6 & 25 & 47 & 59,5 \\
\hline 200 gram & 27,6 & 31,6 & 39,9 & 48,7 \\
\hline 300 gram & 50,6 & 54,8 & 57,5 & 61,1 \\
\hline 400 gram & 66 & 72,3 & 75,7 & 81,9 \\
\hline
\end{tabular}

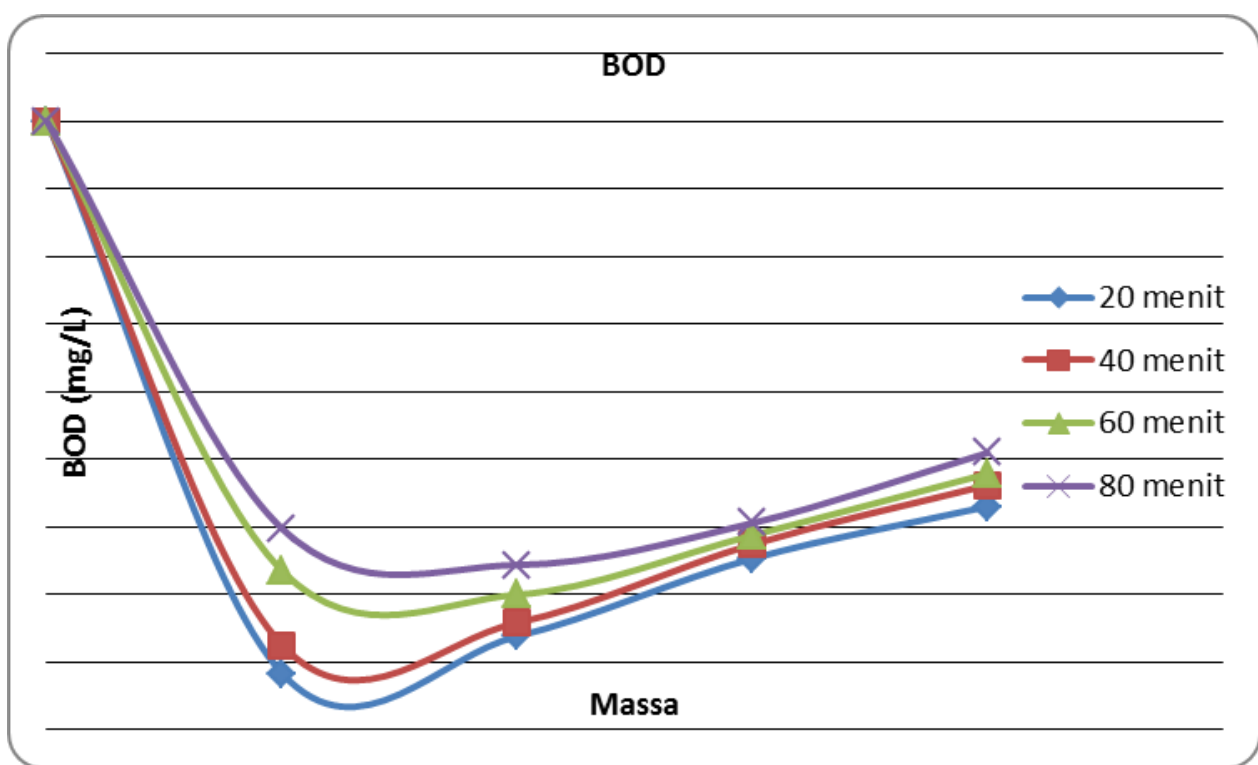

Gambar 5. Hasil Uji Analisa Tentang BOD

Biochemical Oxygen Demand menunjukkan jumlah oksigen terlarut yang dibutuhkan oleh organisme hidup untuk memecahkan atau mengoksidasi bahan-bahan buangan dalam air. Nilai BOD berdasarkan PERGUBJATIM72-2013 yang diperbolehkan adalah sebesar $150 \mathrm{mg} / \mathrm{L}$. Dari hasil analisa sample, semua sample memenuhi standart kelayakan berdasarkan PERGUBJATIM-72-2013. Dengan waktu kontak optimum 20 menit. Hal ini sesuai dengan teori yang telah dijelaskan di tinjauan pustaka bahwa 
semakin lama waktu kontak akan semakin baik dalam proses adsorbsi hingga didapatkan waktu optimum dalam proses penyerapan, setelah waktu optimum didapatkan maka proses penyerapan cenderung berkurang, hal dikarenakan adanya kemungkinan sebagian kecil dari adsorben ikut terbawa oleh larutan sehingga kemampuan penyerapan berkurang. Selain itu juga disebabkan adsorben telah mencapai titik jenuh dalam proses adsorpsi, sehingga proses penyerapan menurun setelah tercapai waktu optimum.
Semakin banyak massa yang ditambahkan maka semakin tinggi pula nilai BOD yang didapatkan. Hal ini sesuai dengan teori yang telah dijelaskan bahwa massa arang aktif sekam padi yang diberikan terlalu banyak sehingga antar arang aktif sendiri saling berdesakan dan menyebabkan interaksi arang aktif sekam padi dengan limbah cair tahu kurang efektif.

Setelah dilakukan uji analisa pendahuluan dan analisa terhadap hasil pengabdian yang dilakukan, maka secara menyeluruh dapat digambarkan melalui tabel sebagai berikut:

Tabel 3. Perbandingan uji analisa pendahuluan dengan hasil penelitian

\begin{tabular}{|c|c|c|c|}
\hline Parameter & Nilai Awal & Nilai Akhir & Selisih \\
\hline COD (mg/L) & 992 & 32 & 960 \\
\hline BOD (mg/L) & 180 & 16,6 & 163,4 \\
\hline
\end{tabular}

Data diatas menunjukkan bahwa arang aktif dari sekam padi, layak digunakan untuk proses adsorbsi limbah cair industri tahu.

\section{KESIMPULAN DAN SARAN Kesimpulan}

1. Proses adsorpsi limbah cair industri tahu menggunakan adsorben arang aktif dari sekam padi dengan ukuran partikel 100 mesh, dapat menurunkan kadar COD dan BOD. Penggunaan arang aktif dari sekam padi yang tepat akan menyerap polutan-polutan yang ada pada limbah dengan maksimal.

2. Semakin lama waktu kontak dan semakin banyak massa adsorben maka semakin tinggi pula kadar COD dan BOD. Hal ini dikarenakan adsorben telah jenuh dan mengalami desorbsi serta antar arang aktif sendiri saling berdesakan sehingga interaksi arang aktif dengan limbah cair tahu kurang efektif.

3. Massa aktif arang aktif sekam padi rata-rata adalah sekitar 20 menit. Setelah itu diduga arang aktif sekam padi telah atau mulai mengalami kejenuhan.

4. Massa arang aktif optimum adalah 100 gram. Semakin banyak massa adsorben yang ditambahkan semakin tinggi pula nilai COD dan BOD, hal ini disebabkan karena massa arang aktif sekam padi yang diberikan terlalu banyak sehingga antar arang aktif sendiri saling berdesakan dan 
menyebabkan interaksi arang aktif sekam padi dengan limbah cair tahu kurang efektif.

\section{DAFTAR PUSTAKA}

Buhani. Modifikasi Silika Dengan Aminopropiltrimetoksisilan Melalui Proses Sol Gel Untuk Adsorpsi Ion Cd(Ii) Dari Larutan. J. Sains MIPA, Desember 2010, Vol. 16, No. 3, Hal.: 177 - 183 ISSN 19781873

Handayani, Novarina Irnaning, dkk. Teknologi pengolahan limbah cair industri tahu sebagai sumber energi dan mengurangi pencemaran air. Seminar Nsional Pangan Lokal, Bisnis dan Eko-Industri semarang. 1 Agustus 2015

Irmanto, Suyata. Penurunan Kadar Amonia, Nitrit, dan Nitrat Limbah Cair Industri Tahu Menggunakan Arang Aktif Dari Ampas Kopi. Jurnal Molekul, Vol. 4. No. 2. November, 2009 : 105 - 114105 Jatyaraga,

Bagas Arya, dkk. Pengaruh massa magnesium silikat (magnesol) dan waktu operasi pada proses pemurnian biodiesel. Peraturan Gubenur Jawa Timur Nomor 72 Tahun 2013. 2013. Jawa Timur.
Purnawan, Candra, dkk. Penurunan kadar protein limbah cair tahu dengan pemanfaatan karbon bagasse teraktivasi.Jurnal Manusia dan Lingkungan, Vol. 21, No.2, Juli 2014: 143-148

Putra ,Riandy, dkk. Adsorpsi Ion Mn(II) Pada Zeolit yang Disintesis dari Abu Dasar Batubara Termodifikasi Ditizon. Prosiding Seminar Nasional Teknik Kimia "Kejuangan" ISSN 1693-4393 Pengembangan Teknologi Kimia untuk Pengolahan Sumber Daya Alam Indonesia Maret 2015

Swastha, Jatu Taufiq. Kemampuang Arang Aktif Dari Kulit Singkong da Dari Tongkol Jagung Dalam Penurunan Kadar COD dan BOD Limbah Pabrik Tahu. Semarang 2010

W. J. Weber Jr. Adsorption processes. The university of michigan, USA. 